\title{
LuKÁš HedMEg
}

Ivan Krasko (Ján Botto) and the Slovak Association of Detvan in Prague

\author{
Pro\&Contra 3
}

No. 1 (2019) 31-45. 



\begin{abstract}
The article focuses on poet Ivan Krasko, his college years spent in Prague and his subsequent membership in the Detvan association. During his five-year stay (1900-1905) in Prague, Krasko became an active and valued member of Detvan. He held offices (auditor and treasurer) and participated in several activities, expanding Detvan's contacts with other student or academic associations. He gave lectures on various topics of interest and occasionally engaged in debates. The second part of the article attempts to reconstruct ongoing contacts and relations between Krasko and some members of Detvan, such as Milan Rastislav Štefánik, Vavro Šrobár, or Mikuláš Scneider-Trnavský, on the basis of their mutual correspondence over the years after their departure from the association.
\end{abstract}

Keywords: Ivan Krasko, Ján Botto, Milan Rastivlav Štefánik, Vavro Šrobár, Mikuláš SchneiderTrnavský, Jaroslav Vlček, Detvan association, Prague.

\title{
Introduction
}

Ján Botto, ${ }^{1}$ (pen name Ivan Krasko), was one of the greatest Slovak poets of the first half of the $20^{\text {th }}$ century. As a representative of Slovak literary modernism ${ }^{2}$ and symbolism, two of his most noted books of poetry are Verše (Verses) and Nox et solitudo (Night and Solitude). His poetry is generally known for expressing feelings and moods of loneliness, pessimism, melancholy and great personal sadness typically located in loosely drawn, grim or autumnal settings. Furthermore, in his poems he focuses on social issues such as the standing of the Slovak nation in contemporary Hungary, social injustice, and the passivity of the young Slovak generation. In his poetry, Botto also explores his feelings of being torn by the internal struggle between his faith and scepticism. His work was greatly influenced by contemporary Czech authors and French symbolists who had established themselves in Europe.

Botto was born on July $12^{\text {th }}, 1876$ in the Gemer county ${ }^{3}$ village of Lukovištia ${ }^{4}$ in the dual monarchy of Austria-Hungary; today it sits in the Slovak district of Rimavská Sobota. He was born to a peasant family, with one of his distant relatives being the

1 Given that Botto did not use his pseudonym while active in Detvan, we refer to him by his birthname in this article.

2 Dana Hučková, Hladanie moderny (Bratislava: Ars poetica - Ústav slovenskej literatúry SAV, 2009), 86-96, 121-131.

3 Contemporary Gömör vármegye.

${ }^{4}$ Contemporary Kőhegy.

Pro\&Contra 1 (2019) 31-45. 
historian Julius Botto and his namesake Ján Botto, one of the most prominent poets of Slovak romanticism and the author of the Death of Jánošik. Many researchers have commented on his choice of pseudonym. Among them Ján Brezina in his book, Ivan Krasko, a literary-historical monography. ${ }^{5}$ The author assumes that one of the reasons Botto created and continued employing his most famous pseudonym, was a continuous intention to distinguish himself from his famous relative. ${ }^{6}$

He attended elementary school for five years in his hometown of Lukovište and then spent his high school years at a secondary grammar school. Botto initially studied at the Hungarian lyceum in Rimavska Sobota ${ }^{7}$ (first five years). After being charged with panSlavism, he went to study at the German lyceum in Sibiu, where he attended his sixth year and then to the Romanian lyceum in Brasov, where he completed his seventh and eighth. ${ }^{8}$ In 1896, he successfully graduated from Brasov's lyceum. Interestingly, it was during these years that he began to write poetry, as his oldest dated poem originates from 1895 , although he had undoubtedly written poems before this. Over the following four years, Botto worked at his relatives' business, the family Kovač from Teplý Vrch, ${ }^{9}$ helping them to grow their enterprise (1896-1897). ${ }^{10}$ In the years 1897-1898 he completed compulsory military service in Trident, Tyrol and Vienna then, in the autumn of 1898, he travelled to Russia, and spent the year 1899 at home again with the Kovác family, where he worked as a supervisor on a factory construction site. ${ }^{11}$

In 1900, Ján Botto arrived in Prague to begin a course in chemistry at the ImperialRoyal Czech Technical University in Prague, today's Czech Technical University (ČVUT). He was matriculated, as evidenced by his preserved matriculation letter, on October $4^{\text {th }}$, 1900. ${ }^{12}$ He successfully completed his studies in the year 1905; these last five years were spent on not only preparing for his future profession but also on developing and shaping his artistic activity. In the years 1900-1904 Botto was also a member of Detvan, the Slovak student association in Prague. ${ }^{13}$

5 Ján Brezina, Ivan Krasko: literárnobistorická monografia (Bratislava: Slovenská akadémia vied a umení, 1946), 108.

${ }^{6}$ His other pseudonyms were Janko Cigáň and Bohdana J. Potokinová. More information: Ján Vladimír Ormis, Slovník slovenských pseudonymov (Martin: Slovenská národná knižnica, 1944), 182.

7 Contemporary Rimaszombat.

8 Both lyceums are located in the territory of today's Romania.

9 Contemporary Meleghegy.

${ }^{10}$ Michal Gráfik, Súborné dielo Ivana Krasku 1. (Bratislava: Vydavatel'stvo SAV, 1966), 196-197.

${ }^{11}$ Brezina, Ivan Krasko, 102-103.

${ }^{12}$ Literárny archív Slovenskej národnej knižnice (LA SNK) Martin - Literary archive of Slovak national library Martin, sign. 75 M 27. Imatrikulačný list Jána Botta 4. 10. 1900.

${ }^{13}$ Ján Zambor, Ivan Krasko a poézia českej moderny (Bratislava: Tatran, 1981), 11-17. 


\section{A Brief Characterization of the Detvan Association in Prague (1882-1914)}

After the division of the Charles-Ferdinand University in Prague in February 1882 into Czech and German parts and creating favourable conditions for studying through the medium of the Czech language, many Slovak students began to study in Czech schools. Young Slovaks in Prague, especially students, thanks to their gradually increasing numbers began to feel the need for their own organizational basis. Among them were Jaroslav Vlček, a student of philology, later a well-known writer and literary historian, and Pavol Socháň, a fine art student and later writer, ethnographer and photographer. Through their combined efforts, they gathered together a group of Slovak students and drafted the proposition for the first statutes for an intended association. They chose to name their fledgling organisation after the lyrical poem Detvan from the Slovak romantic poet Andrej Sládkovič.

With official approval from the Czech Stadtholder, ${ }^{14}$ the association was officially founded at its first general assembly in a café, the old "Slávia" on March $15^{\text {th }} 1882 .{ }^{15}$ The Detvan ${ }^{16}$ association was largely made up of Slovak students studying in Prague. Membership was divided into four subgroups: honorary, founding, supporting and active. During its 32 year of existence (1882-1914), before the outbreak of World War I and the association's ensuing demise, Detvan had 268 active members. According to its first statutes from March 1882:

The aim of the association is to concentrate intelligent Slovaks in Prague who are engaged in mutual education and amusement. The aim will be achieved by a) the founding and tending of a library for the needs of the associations' members, b). reading publications provided by the association, c). providing entertaining and educating lectures during sessions, d). organizing parties. ${ }^{17}$

In the first decade of its life, the association's activities primarily focused on the studying and critical assessment of selected literature works of Slovak and foreign authors, declaiming pieces of older or contemporary Slovak poetry, lecturing on interesting,

${ }^{14}$ In the German language: Statthalterei für das Königreich Böhmen.

${ }^{15}$ Ústav dějin Univerzity Karlovy a archiv Univerzity Karlovy (ÚDAUK) Praha - Institute of history of Charles university and archive of Charles university Prague, fond Všestudentský archiv (VSA), kartón č. B 319, materiály k spolku Detvan. Zápisnica I. valnébo z̧hromaždenia 15. 3. 1882.

${ }^{16}$ Nadežda Jurčišinová, "Zameranie činnosti slovenského spolku Detvan v Prahe (1882-1914)," Annales Historici Presovienses 9, no. 1 (2010): 136.

17 ÚDAUK Praha, fond VSA kartón č. B 301, materiály k spolku Detvan. Stanovy spolku Detvan v Prahe 1882. 
educational topics and developing of Detvan's book collection. Close relationships were maintained with other students and similar Slovak, Czech, Moravian and foreign associations. Among them were the Slovak association in Budapest, the Slovak academic association of Tatran in Wien, Moravská beseda, the Academic reading association of Slavia and many others. In the late 1890's, Detvan's remit was extended to include more social and pro-national topics. These particular activities lasted until the years 1904-1905. The last decade of Detvan's existence was marked by a slow, but noticeable decline. The primary focus was on lecturing and providing financial support for its poverty-stricken members, which was considered at the time to be the most important activity of the association.

Over the years, the Detvan association acquainted the Czechs, primarily inhabitants of Prague, with Slovak culture and nurtured many young Slovaks who after completing their studies left Prague and returned home, where they actively participated in Slovak social and political life. Apart from Ján Botto, the most notable members of Detvan were the historian of literature Jaroslav Vlček, photographer and ethnographer Pavol Socháň, writers Martin Kukučín (Matej Bencúr), Ladislav Nádaši-Jégé and Jozef Gregor Tajovský, politicians Vavro Šrobár and Milan Rastislav Štefánik, painters Joža Uprka and Martin Benka, sculptor František Uprka, composer Mikuláš Schneider-Trnavský and many others.

\section{Ján Botto and his activities in Detvan association}

Based on the association's minute-books, Botto's ${ }^{18}$ name appeared for the first time at the general assembly of $3^{\text {rd }}$ of November 1900,which was held at a Russian café, ${ }^{19}$ while he was member in the years 1900-1904. ${ }^{20}$ Here he was, among the other new members, welcomed by the society's chairman Ivan Fajnor and elected, together with Juraj Nerád, as the association's auditor. Initially, his activity ranged only within his role as an auditor, as during the winter semester of the 1900/1901 academic year, he did not engage in any other activity. This gradually changed when he was elected as

\footnotetext{
${ }^{18}$ Viliam Turčány, “Krasko v Detvane,” Dejiny literatúry 11, no. 6 (1964): 608.

${ }^{19}$ ÚDAUK Praha, fond VSA kartón č. B 301, materiály k spolku Detvan. Zápisnica riadneho valného zhromaždenia 3. 11. 1900.

${ }^{20}$ ÚDAUK Praha, fond VSA kartón č. B 522, materiály k spolku Detvan. Zožnam činmých členov spolku Detvan.
} 
society's treasurer ${ }^{21}$ on March $3^{\text {rd }}, 1901 .^{22}$ Apart from sporadic engagements in plenary debates, Botto began to participate markedly in a critical assessment of the literary pieces read by other members. Members of the Detvan association generally lectured on either Slovak, Czech or foreign literature, or featured their own original titles. Due to the fact that Botto retained anonymity as poet, he did not appear in Detvan's sessions with his own poems. ${ }^{23}$ Instead, he used the nickname Janko Cigán (Johnny Gipsy) However, he often criticized other members of the association. His criticism was often very harsh mostly focussing on linguistic-stylistic aspects and clarity of expression. For example, in March 1901, after Milan Rastislav Štefánik’s lecture on the treatise On liberty by the English philosopher John Stuart Mill, Botto criticized him, asking him "to lecture more Slovak". ${ }^{24}$ The reproach was most likely to be attributed to the fact that Štefánik allegedly did not sufficiently diminish the soft consonants. Also, Gustáv Voda, coming from the territory of today's southern Slovakia, was criticized due to his strong Hungarian accent. Botto proved to be overly critical also of facial expressions and gestures. On the matter of the poetic expression of Ivan Juren he remarked that "the lecturer surely lectures for the first time, and should break from the habit of crude gestures." ${ }^{25}$ Despite his criticism, Botto tried to motivate other members to make more frequent performances by emphasizing the importance of practice advising Gustáv Voda "to declaim more, for it is the only way to improve his Slovak and his public speaking". ${ }^{26}$ Botto, on the other hand, was also able to appreciate the quality of a good speech. E.g. Mr. Guller, for his lecture on the development of the idea of Czechoslovak reciprocity called Our retrospective, was praised "that he never heard such a nice and nicely stylized lecture in the "Detvan" and "He expresses his amazement of such a nice

${ }^{21}$ During this period, the association's meetings were held regularly in the cafeteria of Mr. Hlava (Hlava's Cafe) at the Royal Vineyards (Královské Vinohrady) in Prague. From October 1906, they were moved to other businesses, like the Cafe Royal, also in the Royal Vineyards.

${ }^{22}$ ÚDAUK Praha, fond VSA, kartón č. B 301, materiály k spolku Detvan. Zápisnica riadneho valného z̧̧romaždenia 3. 3. 1901.

${ }^{23}$ František Bublávek, Slovenský spolok "Detvan" v Prabe 1882-1913 (Praha: Nákladom Slovenského spolku "Detvana" v Prahe, 1913), 14.

${ }^{24}$ ÚDAUK Praha, fond VSA, kartón č. B 301, materiály k spolku Detvan. Zápisnica I. riadnej týždňovej schôdzky 9. 3. 1901.

${ }^{25}$ ÚDAUK Praha, fond VSA, kartón č. B 301, materiály k spolku Detvan. Zápisnica I. riadnej týždnovej schôdzky22. 11. 1902.

${ }^{26}$ ÚDAUK Praha, fond VSA, kartón č. B 301, materiály k spolku Detvan. Zápisnica VIII. riadnej týždnovej schôdzky 14. 2. 1903.

Pro\&Contra 1 (2019) 31-45. 
style and pure Slovak." ${ }^{27}$ Botto could express his overly critical attitude even against other members of the executive committee. Especially if he was of the opinion that they were not fulfilling their duties. In one of his comments, Botto "also criticizes the reporter, that his words at the meetings are only superficially recorded." 28

In general, however, Botto was not in the habit of frequently engaging in debates held in association sessions. Apart from his reports as treasurer, many of his recorded performances were quite strict. Typically, he would urge members to adhere to values of justice and morality while in session. He considered it important for Detvan to maintain positive relationships with important personalities of Slovak and Czech cultural or political life. In June 1901, for example, he suggested: "that condolences are to be addressed to doctor Daxner over the death of his mother, the student supporter". ${ }^{29} \mathrm{He}$ also tried to manage regular absences of members from the sessions, which was a long-standing problem that hindered the proper functioning of the association. He suggested "to declare discontent for members who do not attend meetings", ${ }^{30}$ which essentially meant their admonition. The honest and conscientious performance of Botto is confirmed by the fact that there is no such absence record (so-called "dútka") associated with his name. Interestingly, despite his often austere attitude, the records show most of the members of the club referred to him using the informal "Janko" or "Janíčko" (Johnny), which suggests his popularity among the members of Detvan.

With seriousness and responsibility did Botto also approach the function of association's treasurer. He was elected four times in succession to this post, and held it until March $28^{\text {th }} 1903$, when he was discharged. ${ }^{31}$ In the minute-books, it is repeatedly mentioned how he regularly reminded members of their membership fees, procured orders and paid magazine subscriptions. Also, during his tenure the treasury records, audited through balance sheet accounts, were flawless. However, since its foundation, Detvan had faced a continuing lack of funding ${ }^{32}$. Besides financial donations, Detvan's sole source of

${ }^{27}$ ÚDAUK Praha, fond VSA, kartón č. B 301, materiály k spolku Detvan. Zápisnica III. riadnej týždňovej schôdže 7. 12. 1902.

${ }^{28}$ ÚDAUK Praha, fond VSA, kartón č. B 301, materiály k spolku Detvan. Zápisnica IX. riadnej týždňovej schôdzky21. 2. 1903.

${ }^{29}$ ÚDAUK Praha, fond VSA, kartón č. B 301, materiály k spolku Detvan. Zápisnica IX. riadnej týždňovej schôdzky 8. 6. 1901

${ }^{30}$ ÚDAUK Praha, fond VŠA, kartón č. B 301, materiály k spolku Detvan. Zápisnica II. týždňovej schôdžky 9. 11.1901.

31 ÚDAUK Praha, fond VSA, kartón č. B 301, materiály k spolku Detvan. Zápisnica II. riadneho valného z̧̧romaždenia 28. 3. 1903.

32 The Slovak association of Detvan in Prague, in the period before the First World War, operated in the years 1882-1914. 
income was the regular fees of its active, founding and contributing members. In order to improve its financial situation, Botto suggested that "it would be necessary to distribute letters asking for paying membership around Slovakia". ${ }^{33}$ Some members of Detvan were also financially insecure, as they came from a poor Slovak environment. Ján Botto was one of them. Botto attempted to secure some money from one of his unspecified aunts. In the letter, he asks for money: "money, as you well know, I do not have. So far I have lived from those 10 golden coins, which I have forgotten at home and which belong to Detvan. (...) Please therefore send me money for this debt and livelihood I hope you know that I cannot live out of nothing." 34

The Detvan association had repeatedly undertaken steps to distribute magazines of Czech and Slovak origin in order to raise awareness of the serious socio-political and cultural issues in Austria-Hungary. Chosen members of the association were designated to receive prepaid or free periodicals. Their task was to study the contents of the periodicals and then to submit a summary in report form. This made it possible for all the members of the association to be aware of their content, even if they were unable to read the magazines either because of lack of time or interest. Botto was one of these members. Soon after his arrival in the association, in the summer semester of 1901, he was assigned the magazine Národný hlásnik and the Ludové noviny. ${ }^{35}$ Interestingly, Botto did not fail to show his artistic tendency even in this task. While, for example, during the summer semester of 1903, Štefánik lectured about Cirkevné listy, the Katolícke noviny, and Bohdan Pavlů about Slovenské pohl'ady and Časkoslovenská vzájomnost', Botto only undertook Dennica (Morning star). ${ }^{36}$

Detvan also received several Hungarian journals. The issue of subscribing offers an interesting glimpse into Botto's opinions. At the end of November 1902, Botto adamantly opposed Štefánik's proposal, at that time chairman of the association, that Detvan request from different editorial offices of Hungarian magazines to send them free copies. Botto suggested that they be subscribed because, according to his opinion, "the association should not humiliate itself and ask for free magazines from our biggest enemies." ${ }^{37}$

${ }^{33}$ ÚDAUK Praha, fond VSA, kartón č. B 301, materiály k spolku Detvan. Zápisnica III. riadnej tý́ž́dnovej schôdžky 7. 12. 1902.

${ }^{34}$ LA SNK Martin, sign. 75 CH 27. List Jána Botta Bližšrie nemenovanej tete 2. 11. 1903.

35 ÚDAUK Praha, fond VSA, kartón č. B 301, materiály k spolku Detvan. Zápisnica I. riadnej tý̌̃únovej schôdžky 9. 3. 1901.

${ }^{36}$ ÚDAUK Praha, fond VSA, kartón č. B 301, materiály k spolku Detvan. Zápisnica VIII. riadnej týždñovej schôdzkyy 14. 2. 1903.

${ }^{37}$ ÚDAUK Praha, fond VSA, kartón č. B 301, materiály k spolku Detvan. Zápisnica I. riadnej týž̃unovej schôdzlky 22. 11. 1902.

Pro\&Contra 1 (2019) 31-45. 
Botto's proposal was overturned, due to Štefánik's argument, "that it is almost customary in all associations to ask for free magazines". ${ }^{38}$

More direct insight into Botto's opinions about cultural relations with Czechs, ideas on Czechoslovak ${ }^{39}$ reciprocity $^{40}$, contemporary Hungarian politics and its associated social issues can be gleaned from his reaction to the aforementioned lecture Our retrospective - Naśa retrospektiva presented by medical student Eduard Guller. A week after the said lecture, Guller recorded Botto's thoughts on the matter:

"Our Slovak, especially Slovak culture is weak, poor, we do not actually have our culture in the broader sense. We and our culture cannot even be developed under Hungarian bayonets. Regarding speech, however, our Slovak language seems to be prettier than Czech, But as far as culture is concerned, we definitely have to accept Czech, respectively Czech culture, which is undoubtedly nice, developed, which stands the test of time and which - I deliver - not only it is equal to the Hungarian culture but in many cases, it is far ahead of it. We Hungarian Slovaks have a choice between Hungarian and Czech culture. For we alone are weak to develop a peculiar, independent, own culture, therefore it is our duty to join the Czech culture. If we were to adopt the Hungarian culture, we would cease to be Slavs." ${ }^{41}$

Given the fact, that this research attempts to reconstruct Botto's activities, and the forming of his political and social views during his membership of Detvan, it can only be achieved on the basis of his statements and appearances in association sessions which were less frequent. ${ }^{42}$ However, here we can observe Botto's strong disapproval of the contemporary national politics of the Hungarian government, especially the process of Hungarization, as a cultural and language assimilation of other non-Hungarian nationalities in the Hungarian part of the dual-monarchy. This mindset strongly influenced his views on the significance of the Slovak language and culture in relation to the Czech. As an emerging representative of Slovak nationalism, he saw an alternative future for CzechSlovak cooperation due to the common Slavic origin of both nations as more preferable and appropriate to the subsumption into one state with the Hungarians.

${ }^{38}$ ÚDAUK Praha, fond VSA, kartón č. B 301, materiály k spolku Detvan. Zápisnica I. riadnej týždňovej schôdzky 22. 11. 1902.

${ }^{39}$ Czechoslovak reciprocity is a term referring to a political movement that originated in Czech and Slovak nationally oriented environments at the turn of the 19th and 20th century and was a result of escalating tensions caused by the national policy of the Hungarian government toward Slovaks.

${ }^{40}$ Nadežda Jurčišinová, Českoslovanská jednota a Slováci (1896-1914) (Prešov: FF PU, 2010), 91-95.

${ }^{41}$ ÚDAUK Praha, fond VSA, kartón č. B 301, materiály k spolku Detvan. Zápisnica IV. riadnej týždňovej schôdžky 14. 12. 1902.

${ }^{42}$ With this in mind, on the basis of available archival documents from this period, we are unable to reconstruct Botto's view on other nations such as Germans, Poles or Russians. 
In the interest of expanding Detvan's contacts within the Czech environment and promoting the idea of Czech-Slovak reciprocity, Botto lobbied for Detvan's membership of the Union of Czech Students at the beginning of February 1902. Admission was hampered by fears of inappropriate actions by the Union. Botto argued that "in the case, that cliquefication takes reign in the Union, the club could withdraw without any inconvenience”. He proposed Ján Procházka for the committee and Milan Sloboda as a substitute, while Krasko was particularly interested in the approach of the Union towards Corda Fratres (the International Federation of Students), founded in Turin in 1898. ${ }^{43}$ Botto's positive attitudes towards developing relations between the Slovaks and Czechs can be evidenced in several of his lectures and comments. For instance, in the lecture From the time of our awakening by Štefánik, "he would have liked more from the biography of Rudolf Pokorný because this man has great merit for Czech-Slovak reciprocity".44 Botto worked with Štefánik in the development of Czech-Slovak reciprocity at a party of Moravian Slovaks in February 1903, which was organized by the Academic Section of Czechoslovak Unity. The delegation represented Detvan in an attempt to establish contacts between Slovak and Moravian students. ${ }^{45}$ Botto also occasionally submitted proposals for the purchase of new book titles for the association's library and was careful not to forget the publishing activities of affiliated Slovak student societies. One of them, the Nation in Vienna, was founded in 1892 as the successor of Tatran, had its activities stopped. In December 1902, Botto at the Detvan meeting “announces that the 'Nation' of Vienna has issued 'Almanach' and proposes its purchase". ${ }^{46}$

Interestingly, Botto occasionally participated in the debates that typically followed lectures: on November $14^{\text {th }}$, Milada Sísová, Czech redactor, publicist and feminist presented to the association's weekly meeting her lecture About writers to whom woman was a problem - O spisovateloch, ktorým bola žena problémom. Among others, Botto took part in the debate and we learn that "Brother Botto liked the lecture. However, he reproached the fact, that she omitted opinions of Slavic man, such as Tolstoy or Turgenev. She did not

${ }^{43}$ ÚDAUK Praha, fond VSA, kartón č. B 301, materiály k spolku Detvan. Zápisnica z IX. riadnej týž́dňovej schôdzrky 8. 2. 1902.

${ }^{44}$ ÚDAUK Praha, fond VSA, kartón č. B 301, materiály k spolku Detvan. Zápisnica VI. riadnej týž́dñovej schôdžky 24. 1. 1903.

${ }^{45}$ ÚDAUK Praha, fond VSA, kartón č. B 301, materiály k spolku Detvan. Zápisnica VII. riadnej týž̃uñovej schôdzky 1. 2. 1903.

${ }^{46}$ ÚDAUK Praha, fond VSA, kartón č. B 301, materiály k spolku Detvan. Zápisnica III. riadnej týž̃unovej schôdžky 7. 12. 1902. 
contrast German and Slavic woman, and that has a great meaning for us." 47 This meeting was later an inspiration for Botto's prosaic piece, a portrait study called Naši, published in 1907 in Slovenský obzor (Slovak horizon). Ján Botto, however, did not begin to develop his own lecture activity in Detvan's sessions until 1904. Based on associations' records, it can be assumed that Botto did not share his literary work with other members of Detvan, and most likely concealed it. This caused the lectures to be directed towards his field of study - chemistry and various related technical fields. Several times he was even forced to improvise because pre-arranged lecturers did not show up. At the end of February 1904, he lectured On Agriculture. Here, Botto "gave a short historical outline of the economy from the oldest times to the latest times. He mentioned the Egyptians, the Jews, the Greeks, the Romans, and the Middle Ages. - He talked about the superstition from middle ages, where the crop shortage or abundance were attributed to the supernatural beings." 48 In his lecture About the production of glass "he explained the production of glass in the old days and times of the present, he also outlined the means of production and the chemical composition of simple glass and beautifying glass." ${ }^{49}$

Botto's name appears only sporadically in the association's records and attendance lists from the spring of 1904 as he prepared to finish his studies. Botto was mentioned for the last time at a committee meeting at the end of February 1905. He is already listed as a guest, in the records, as he was no longer a student and legitimate member of Detvan in Prague. ${ }^{50}$

\section{Ján Botto's Correspondence with other Members after their Departure from the Association}

Relatively well-preserved contemporary correspondence allows us to recreate the character of Ján Botto and his relationships with selected members of the association after his departure from Detvan. Ján Botto had, during his college studies and membership in Detvan a friendly relationship with the astronomy student and three-times chairman of the association, Milan Rastislav Štefánik. Their numerous, often humorous, correspondence in which the tendency to open communication prevailed reflects their deep friendship. After

${ }^{47}$ ÚDAUK Praha, fond VSA, kartón č. B 301, materiály k spolku Detvan. Zápisnica XV. riadnej týžđdñovej schôdžky 14. 11. 1903.

${ }^{48}$ ÚDAUK Praha, fond VSA, kartón č. B 301, materiály k spolku Detvan. Zápisnica VI. riadnej týž́dñovej schôdžky 22. 2. 1904.

${ }^{49}$ ÚDAUK Praha, fond VSA, kartón č. B 301, materiály k spolku Detvan. Zápisnica IX. riadnej týž́dñovej schôdžky 13. 3. 1904.

${ }^{50}$ ÚDAUK Praha, fond VSA, kartón č. B 301, materiály k spolku Detvan. Zápisnica VIII. výborovej schôdžky 25. 2. 1905.

Pro\&Contra 1 (2019) 31-45. 
completing his education in 1904 and leaving the association for France, Štefánik became the collaborator of a major astronomer, Pier Jula Jensen at the Meudon Observatory in Paris. His desperate financial situation eventually forced him to write to Botto: "I have only a few francs in my pocket...you have to help me...I need about 30-40 golden coins. For some time, I have only been eating once a day, I am poor, and I am angry at this order of the world. But, I feel content, I knew I would not have a bed of roses prepared for me." ${ }^{51}$ After leaving the association, they often sent each other postcards. Of particular interest are the postcards sent by Štefánik from his travels around Europe, which are often supplemented with various amusing texts. One postcard depicting the Basilica of Saint Paul is addressed to segnor Giovanni Botto, bearing the inscribed text: "I prayed today, my dear Johnny, for your sinful soul in the temple of St. Peter. Yours Milan." 52

Botto also maintained friendly relations with former member, Fedor Albini, a construction engineer, publicist and later, prefect of the State Land Office in Prešov. This is demonstrated by his congratulations on Botto's wedding: "I read - I do not believe my eyes - was it you, the harsh ascetic, to marry, if so, there is nothing else left, only to wish you a lot of luck." 53

Several letters are preserved from pre-war correspondence between Vavro Šrobár, a member of the Hlasism ${ }^{54}$ movement and post-war politician, and Ján Botto, dated in the decades following their college education and membership of Detvan, despite the two not being in the association at the same time. Most of these were "lighter" in content, e.g. Šrobár's letters to Botto thanking him for his congratulations on the occasion of the appointment of Šrobár as a university professor ${ }^{55}$ in 1935, or for an unspecified poetry collection in which Šrobár writes to Botto: “Thank you for the beautiful book of poems I was so glad to read and appreciate. I hope that I will soon reciprocate with some new literary work." ${ }^{56}$ In their correspondence, however, there are also letters with a much more serious tone. E.g. in a letter from 1945, in which he recalls years of mutual friendship and

${ }^{51}$ LA SNK Martin, sign. 75 H 4. List Milana Rastislava Štefánika Ivanovi Kraskovi so žiadostón o finanónú pomoc 1906.

${ }^{52}$ LA SNK Martin, sign, 75 H 4. Pohl’adnica Milan Rastislava Śtefánika Ivanovi Kraskovi z Rima.

${ }^{53}$ LA SNK Martin, sign. 75 A 1. Svadobné blaboželanie Fedora Albinibo Ivanovi Kraskovi 27. 9. 1911.

${ }^{54}$ The Hlasism movement was an association of nationally oriented, dominantly Slovak intelligence. The group was centered around Hlas (Voice) magazine (1898 - 1904), hence the name Hlasism. The aims of the movement were a moral renewal of the Slovak nation and society, civil rights and freedoms, activation of political, economic and cultural life, and democratic reforms in contemporary Hungary. As supporters of Czech-Slovak cooperation, the most important figures of the Hlasism movement were Tomáš Garrique Masaryk or Vavro Šrobár.

${ }^{55}$ LA SNK Martin, sign. 75 G 51. Dakoovný list Vavra Šrobára Ivanovi Kraskovi 7. 10. 1935.

${ }^{56}$ LA SNK Martin, sign. 75 G 51. D́akovný list Vavra Šrobára Ivanovi Kraskovi 19. 4. 1937. 
cooperation with Botto, he writes: "I remember vividly our cooperation, our plans, our aspirations, and our shared joyful moments (...) we made plans of better future for us and our descendants, a new generation to receive the legacy their fathers." ${ }^{57}$

Botto also maintained contacts with literary historian, Czechoslovak politician and historically first chairman of the Detvan association, Jaroslav Vlček. E.g. In 1922 Vlček informed Botto about the preparation of the unveiling of the memorial plaque to Pavol Jozef Šafárik: "A literary speaker at the unveiling of the plaque of Šafárik in Gemer will be Jožko Škultéty and Štefan Krčméry offered to write a leaflet for the wider audience..."58 This letter documents Botto's interest in his home region of Gemer even years after his departure.

Botto also held an extensive, archived, correspondence with his long-time friend and association colleague, the important Slovak composer, Mikuláš Schneider-Trnavský. This close relationship is evidenced firstly by the various friendly names they addressed each other with such as "Dear Janko" or "Janíčko". Interestingly, they also maintained a work related relationship to a certain extent, as Schneider-Trnavský put to music several of his poetic pieces as well as translating Botto's collection of poems, Vesper dominicae, into the German language. This topic is the theme of several letters. ${ }^{59}$ However, more interesting are the letters in which both artists reminisce on their student years, like, for example, in the letter of $27^{\text {th }}$ March 1956: "You know, my dear Janíčko, when I think of you, the most beautiful memories of spring of my life pop up. We were young, handsome boys, there was only love, only heart! There were a lot of us, and all of us have engaged in sincere friendship without envy and hatred." ${ }_{60}$ Among their mutual correspondence there is also to be found congratulations on various life anniversaries. The last Schneider letter, pertinent to the subject under study, is the letter of condolences from Mikulás Schneider-Trnavský to Elena Bottová, the widow of Ján Botto, who died on March $3^{\text {rd }}$, 1958. Schneider-Trnavský writes: "The great Son of our nation has left!... It is a pity of His golden heart, His kind eyes, and His Light, which will never stop shining until there is a faithful Slovak on this mournful Earth." ${ }^{\prime 1}$

57 LA SNK Martin, sign. 75 G 51. List Vavra Šrobára Ivanovi Kraskovi 4. 8. 1945.

${ }^{58}$ LA SNK Martin, sign, 75 H 44. List Jaroslava Vľ̌eka Ivanovi Kraskovi 22. 3. 1922.

${ }^{59}$ LA SNK Martin, sign. 75 G 2 a. List Mikuláša Schneidear-Trnavského Ivanovi Kraskovi o preklade zbierky Vesper dominicae 26. 12. 1942.

${ }^{60}$ LA SNK Martin, sign. 75 G 2 a. List Mikuláša Schneidera-Trnavského Ivanovi Kraskovi 27. 3. 1956.

${ }^{61}$ LA SNK Martin, sign. 75 N 49. Kondolencia Mikuláša Schneidera-Trnavského Hane Bottovej 4. 3. 1958. 


\section{Conclusion}

Ján Botto (Ivan Krasko), one of the greatest Slovak poets of the first half of the $20^{\text {th }}$ century was, during his university studies a member of the Slovak association, Detvan in Prague (1900-1904). Within the association, Botto served as a treasurer, participated in various debates and later, lectured on topics concerning chemistry and technical subjects. Despite the anonymity he retained over his artistic activities, he often criticized the artistic performances of others. He tended to encourage other members to be literarily and socially active. Similar social-political opinions on Czech-Slovak relations and reciprocity were shared with his long-time friend and association colleague, Milan Rastislav Štefánik, with whom he maintained contact, even after their departure from Detvan. Ján Botto was in contact with other former members of Detvan as well, among which were Fedor Albini, Vavro Šrobár, Jaroslav Vlček, and Milan Schneider-Trnavský.

\section{References}

Brezina, Ján. Ivan Krasko: literárnobistorická monografia. Bratislava: Slovenská akadémia vied a umení, 1946.

Bublávek, František. Slovenský spolok "Detvan"v Prahe 1882-1913. Praha: Nákladom Slovenského spolku "Detvana” v Prahe, 1913.

Gráfik Michal. Súborné dielo Ivana Krasku 1. Bratislava: Vydavatel’stvo SAV, 1966.

Hučková, Dana. Básnické dielo - Ivan Krasko. Bratislava: Kaligram, 2005.

Hučková, Dana. Hladanie moderny. Bratislava: Ars poetica - Ústav slovenskej literatúry SAV, 2009.

Jurčišinová, Nadežda. Ceskoslovanská jednota a Slováci (1896-1914). Prešov: FF PU, 2010.

Jurčišinová, Nadežda. "Zameranie činnosti slovenského spolku Detvan v Prahe (18821914).” Annales Historici Presovienses 9, no. 1 (2010): 136-157.

Mečiar, Stanislav ed. Detvan 50 rokov v Prahe. Rozpomienky stúdie, úvaby. Praha: Slovenský akademický spolok Detvan - Matica Slovenská, 1932.

Ormis, Ján Vladimír. Slovník slovenských pseudonymov. Martin: Slovenská národná knižnica, 1944.

Turčány, Viliam. “Krasko v Detvane.“ Dejiny literatúry 11, no. 6 (1964): 607-620.

Zambor, Ján. Ivan Krasko a poézia českej moderny. Bratislava: Tatran, 1981.

Pro\&Contra 1 (2019) 31-45. 